\title{
EFFECT OF SELECTION FOR HIGH AND LOW ANTIBODY RESPONSE AGAINST SHEEP RED BLOOD CELLS ON HORMONAL PROFILE DURING IMMUNE RESPONSE IN CHICKENS
}

\author{
A. M. Abdou ${ }^{1}$, A. M. M. Atta ${ }^{1}$, S. M. T. El-Tantawy ${ }^{1}$, S. S. Siam ${ }^{2}$ and \\ A.M. Rezk ${ }^{2}$ \\ 1- Department of Animal Production, Faculty of Agriculture, University of Cairo, \\ Giza, Egypt, 2- Animal Production Research Institute, Ministry of Agriculture, \\ Dokki, Egypt
}

\section{SUMMARY}

Two experiments were conducted in this study using two lines of Fayoumi chickens divergently selected for high $(H)$ and low $(L)$ antibody response against sheep red blood cells (SRBC) for four generations. The objectives of this study are to compare humoral and cell mediated immune responses between the lines, as well as to monitor the $T_{3}$ and corticosterone hormone profile during the initiation of the immune responses.

In the first experiment one hundred male chicks of each line were primary injected intramuscular with either $1 \mathrm{ml} 25 \%$ SRBC suspension or saline at 50 and secondary reinjected at 80 days of age. Blood samples were collected at 0, 1, 3, 6, 9, 12 and $24 \mathrm{~h}$ and at 3, 7 and 10 days following primary and secondary injection. The results showed that $H$ line produced significantly higher primary and secondary antibody titer than $L$ line at 7 and 10 days post injection. The results showed that $T_{3}$ levels decreased significantly at $3 \mathrm{~h}$ in $\mathrm{H}$ line and at 3, 6 and $9 \mathrm{~h}$ in L line, then remained at low levels till 10 days post primary SRBC injection as compared to $0 \mathrm{~h}$. Within both $\mathrm{H}$ and $\mathrm{L}$ lines, the $\mathrm{T}_{3}$ level showed insignificant differences between $0 \mathrm{hr}$ and at any time post secondary SRBC or saline injection (except that in $H$ line at $3 \mathrm{~h}$ post SRBC injection). In both line there was a significant increase in corticosterone levels at 24h as well as at 3, 7 and 10 days post primary, and at 3,7 and 10 days post secondary SRBC injection as compared to $0 \mathrm{~h}$.

In the second experiment, one-hundred and twenty male chicks of each line were injected intradermally into wattle with either $100 \mu \mathrm{g}$ PHA-P or saline at 56 days of age to monitor the delayed type hypersensitivity $(D T H)$ reaction. Blood samples were collected at 0, 3, 6, 9, 12 and, 24 hs post injection. The results indicate that $H$ line had higher DTH value at 12 and $24 \mathrm{~h}$ than that in $L$ line at the same time point. There was no remarked change in the level of $T_{3}$ or corticosterone between PHA-P and saline injected birds at any time point following injection within both lines.

In conclusion, the results of $T_{3}$ or corticosterone levels in the current study may explain that the initiation of humoral immune response involves the activation of HPT- and HPA-axis. While this axis is not involved in delayed type hypersensitivity reaction.

Keywords: Chicken, immune response, divergent selection, $T_{3}$, corticosterone

Issued by The Egyptian Society of Animal Production 


\section{INTRODUCTION}

Disease resistance in animals is a result of the interaction of the animal's environment and its genetic component, so the relationship between genetic make-up and immunity has been studied extensively (Gehad et al., 1999; Ahmed,2004). Biozzi et al., (1982) indicated that the different branches of avian immune system are under independent genetic control. So it has been common practice now to enhance disease resistance through genetic improvement represented by divergent selection for antibody production against polyvalent non-pathogenic T-dependent antigen (such as SRBC).

The immune system is a system that is very much integrated into the total physiology of the animal (Marsh, 1992). From this integration, is the bi-directional communication between the neuro-endocrine and the immune system that allow the organism to withstand immunologic challenges without disturbance of body homeostasis (Davis, 1998). Kruger (1996) has demonstrated that the immunoregulatory effects of the hypothalamus-pituitary-thyroid (HPT) axis is quite diverse and influence different aspects of the immune system physiology. Thyroid hormones exert a regulatory effect on humoral immunity more than a stimulatory one (Trout et al., 1988 and Marsh, 1992). Moreover there is a strong hypothesis that thyroid hormones exert effect on cell-mediated immunity through their action on the maturation and function of thymus-derived lymphocytes and this action is mediated by genetic background of the animal (Marsh, 1992).

Similarly the communication between the immune system and hypothalemopituitary-Adrenal axis (HPA axis) seems crucial to the proper function of immune system. Mashaly et al. (1998) found that the first step in the initiation of humoral immunity is the release of IL-1 by macrophages which in turn stimulates CRF by hypothalamus, then CRF stimulates ACTH production by anterior pituitary and / or Leukocytes; additionally CRF will directly enhance lymphocyte activities in the spleen. Then corticosteroid production will be stimulated by ACTH and will cause redistribution of lymphocytes from circulation to secondary lymphoid organs such as the spleen for antigen processing and eventual production of antibodies against the invading antigens.

Finally, both ACTH and corticosterone will interact in a negative feed back manner to regulate and control the process of antibody production by inhibiting lymphocyte activity and/ or reducing the responsiveness to different stimuli. Glucocorticoids also limit cell- mediated immune response in chickens (Murray et al., 1987).

The objectives of this study are:

1- To evaluating the humoral as well as the cell-mediated immune parameters between two lines of Fayoumi chickens divergently selected for high $(\mathrm{H})$ and low (L) humoral immune response against SRBC for four generations.

2- To detect the tri-iodothyronine $\left(\mathrm{T}_{3}\right)$ and corticosterone hormone profile within lines during primary and secondary immune response as well as along different phases of delayed type hypersensitivity (DTH). 


\section{MATERIALS AND METHODS}

Two experiments were conducted and carried out at Poultry Research Center, Animal Production Department, Faculty of Agriculture, Cairo University, Giza. Egypt. The experimental flock compared two lines of Fayoumi chickens selected for high $(\mathrm{H})$ and low $(\mathrm{L})$ antibody response against sheep red blood cells (SRBC) for four generations.

\section{General Management}

At day of hatch, all chicks were wing banded; then placed intermingled in floor brooder pens which contained wood shaving litter, hanging tube feeder and plastic drinker. The birds were exposed to continuous light during the first three days of age and thereafter they were exposed to natural day light. They were fed commercial starter ration $(20 \%$ crude protein and $2800 \mathrm{~K}$. cal $\mathrm{ME} / \mathrm{Kg})$. All chicks were vaccinated against Newcastle disease virus at 7,22 and 57 days of age; against infection bursal disease at 14 and 24 days and against infection fowl box disease at 35 days of age.

\section{Experimental Protocol}

The first experiment was conducted to monitor the early events during the initiation of the primary and secondary humoral immune response following the injection of SRBC antigen in both $\mathrm{H}$ and $\mathrm{L}$ lines which is the release kinetics of the $\mathrm{T}_{3}$ and corticosterone hormone following the injection of SRBC antigen to determine the possible differences between lines.

The second experiment was conducted to investigate the changes in circulating levels of $\mathrm{T}_{3}$ and corticosterone during the development of the delayed type hypersensitivity (DTH) response.

\section{First Experiment}

One hundred chicks of each line were used in the first experiment. At 50 days of age, chicks of each line were divided into two groups (50 birds for each group). The first group was injected intramuscular with $1 \mathrm{ml} 25 \%$ SRBC suspension to determine primary response, whereas the second group was injected with $1 \mathrm{ml} 0.9 \%$ saline to be served as a control group. To determine the secondary immune response, the same birds of each group were injected at 80 days of age with the same schedule followed in the primary response.

Five birds from each group of each line were bled just before injection (zero $h$ ). Five additional birds from each group of each line were bled at 1, 3, 6, 9, 12 and $24 \mathrm{~h}$ and at 3, 7 and 10 days following primary and secondary injection. No bird was bled more than once to ensure that handling the birds would not affect corticosterone levels. Approximately $3 \mathrm{ml}$ of blood was drawn from the brachial vein of each bird. The samples were allowed to clot to provide serum for antibody titer and hormone assays.

\section{Antibody titer}

The samples of 3, 7 and 10 days post SRBC injection were used to determine primary and secondary immune response using micro titer technique described by Van Der Zijpp and Leenstra (1980). 


\section{Hormonal profile changes during humoral immune responses}

Concentration of circulating $\mathrm{T}_{3}$ and corticosterone were measured in all blood samples collected at the different times following SRBC or saline injections. The hormones were measured using radio immunoassay (RIA) kits purchased from Cambridge Medical Diagnostic Lab (Billeezica MA).

\section{Second Experiment}

At 56 days of age, one-hundred and twenty birds of each line were used in this experiment to study DTH reaction. The birds within each line were divided into two equal groups (60 birds for each one). The first group was injected intradermally into the right wattle using $100 \mu \mathrm{g}$ PHA-P prepared in $1 \mathrm{ml}$ sterile saline. The second group was injected intradermally into the right wattle using $0.1 \mathrm{ml}$ of sterile saline. The wattle thickness was measured at $0,3,6,9,12$ and $24 \mathrm{hr}$ following PHA-P or saline injection using a digital micrometer. The percentage increase in wattle thickness was calculated according to the following equation:

(Wattle thickness after injection - initial wattle thickness)/ initial wattle X 100.

\section{Hormonal profile changes during DTH reaction}

Six blood samples were drawn from both PHA-P and saline injected groups at the same time of measuring wattle thickness. The concentrations of $\mathrm{T}_{3}$ and corticosterone were measured in all serum samples collected at the different times following PHA-P or saline injections using Radio-Immunoassay (RIA) kits and the technique was as previously mentioned.

\section{Statistical analysis}

Data were analyzed using three-way analysis of variance (general liner models procedure, SAS Institute, 2000). The sampling time, injection treatment (SRBC, PHA-P or saline) and line, were used as the main effects in statistical analysis of hormonal profile changes. While one-way analysis was used through out antibody titer and DTH using the line as a main effect. Mean values were compared according to Duncan (1955).

\section{RESULTS AND DISCUSSION}

\section{First Experiment}

\section{Antibody Titer against SRBC}

The results in Table 1 showed that $\mathrm{H}$ line produced significantly higher primary and secondary antibody titer than L line at 7 and 10 days post injection. However, no significant differences were found between the two lines at 3 day post injection. These results are in agreement with those reported by Kreukneit et al. (1996); Parmentier et al. (1996); and Ahmed (2004). They found differences between lines in antibody response against SRBC (T-dependent antigen). The difference is also in agreement with Scott et al. (1994) and Nelson et al. (1995), who reported a similar difference in antibody titer against Brucella abortus (T-independent antigen). 
Table 1. Means \pm SE of primary and secondary antibody titer against sheep red blood cells of high and low lines of Fayoumi chickens

\begin{tabular}{|c|c|c|c|}
\hline \multirow{2}{*}{ Line } & \multicolumn{3}{|c|}{ Days post immunization } \\
\hline & 3 & 7 & 10 \\
\hline & \multicolumn{3}{|c|}{ Primary immune response } \\
\hline High & $3.66 \pm 0.67^{\mathrm{a}}$ & $5.66 \pm 0.67^{\mathrm{a}}$ & $3.00 \pm 0.00^{\mathrm{a}}$ \\
\hline \multirow[t]{2}{*}{ Low } & $2.33 \pm 0.33^{\mathrm{a}}$ & $3.00 \pm 0.30^{\mathrm{b}}$ & $2.00 \pm 0.00^{\mathrm{b}}$ \\
\hline & \multicolumn{3}{|c|}{ Secondary immune response } \\
\hline High & $4.00 \pm 0.58^{\mathrm{a}}$ & $6.66 \pm 0.33^{\mathrm{a}}$ & $5.00 \pm 0.00^{\mathrm{a}}$ \\
\hline Low & $2.66 \pm 0.33^{\mathrm{a}}$ & $3.33 \pm 0.33^{b}$ & $3.00 \pm 0.00^{\mathrm{b}}$ \\
\hline
\end{tabular}

Several investigations have been done to explain the immune differences between lines. Van Der Zijpp et al. (1989) and Scott et al. (1994), have demonstrated that the variation between lines in antibody production could be attributed to macrophages's ability to identify and present antigens on their membranes where the antigen is rapidly catabolized in low line and vice versa in high line. Moreover Siegel et al. (1992) and Kreukniet et al. (1996), have confirmed that a higher percentage of CD4+ cells (T-helper cells) are present in the spleens of $\mathrm{H}$ lines, while higher percentage of CD8+ cells (cytotoxic T-cells) are located in L line's spleen.. The previous observation has been confirmed by Siegel et al. (1992), who have found that there was higher percentage of B-cells in the spleens and blood of $\mathrm{H}$ line than $\mathrm{L}$ line of chickens.

\section{Hormonal profile changes associated with humoral immune response: \\ A) Profile of Serum $T_{3}$ Hormone}

The results in Table 2 show that $\mathrm{T}_{3}$ levels of $\mathrm{H}$ line decreased significantly at $3 \mathrm{~h}$ and remain low till 10 days post primary and secondary SRBC injection as compared to $0 \mathrm{~h}$. Moreover, within saline injected birds, the results didn't have a clear pattern or any significant change (except that at $9 \mathrm{~h}$ pos primary injection). The results of SRBC injected birds of $L$ line showed a significant decrease in $T_{3}$ level at 3,6 and 9 $h$ post primary SRBC injection (Table 2). On the other hand, no significant differences were observed in $\mathrm{T}_{3}$ levels of saline injected birds of $\mathrm{L}$ line as compared to $0 \mathrm{~h}$.

With respect to secondary immune response within $L$ lines, the $T_{3}$ level showed no significant differences between $0 \mathrm{~h}$ and any other time post-SRBC injection (Table 2). Regardless the interline difference, there were no significant differences between SRBC and saline injected birds at any sampling time point of primary and secondary immune response. Additionally, no differences were observed between pooled means of $\mathrm{T}_{3}$ levels of $\mathrm{H}$ and $\mathrm{L}$ lines during either primary or secondary immune response (Table 3).

Trout et al. (1988) recorded a decrease in $\mathrm{T}_{3}$ during the first day and then an increase by day 2 post-antigen injections. Furthermore, Atta (2002) revealed that $T_{3}$ level decreased significantly at $3 \mathrm{~h}$ post SRBC injection compared to $0 \mathrm{~h}$ in White Leghorn chicken. The study of Martin and Siegel (1988) explained a magnitude 
difference between $\mathrm{H}$ and $\mathrm{L}$ lines in $\mathrm{T}_{3}$ concentration, which may explain the association between thyroid hormone levels and antibody titers.

Table 2. Change in serum $T_{3}$ level (n mol/L) in SRBC and saline injected of of high and low lines of Fayoumi chickens

\begin{tabular}{|c|c|c|c|c|c|c|c|c|c|c|c|}
\hline \multirow{3}{*}{ Line } & \multirow{3}{*}{ Treatment } & \multicolumn{10}{|c|}{ Primary immune response } \\
\hline & & \multicolumn{7}{|c|}{ Time post injection ( Hours) } & \multicolumn{3}{|c|}{$\begin{array}{c}\text { Time post } \\
\text { injection (days ) }\end{array}$} \\
\hline & & $\mathbf{0}$ & 1 & 3 & 6 & 9 & 12 & 24 & 3 & 7 & 10 \\
\hline \multirow{3}{*}{ High } & SRBC & 4.2 & 3.9 & 2.2 & 2.4 & 2.6 & 2.9 & 2.8 & 3.8 & 3.2 & 3.0 \\
\hline & & \pm .6 & \pm .4 & $\pm .7^{*}$ & \pm .8 & \pm .4 & \pm .2 & \pm .2 & \pm .7 & \pm .2 & \pm .6 \\
\hline & Saline & 4.2 & 2.8 & 2.9 & 3.3 & 2.7 & 3.3 & 3.7 & 2.9 & 4.3 & 4.4 \\
\hline \multirow{6}{*}{ Low } & & \pm 0.6 & +0.3 & \pm 0.5 & \pm 0.2 & $+0.4^{*}$ & \pm 0.4 & \pm 0.3 & \pm .6 & \pm 0.1 & \pm 0.3 \\
\hline & SRBC & 5.0 & 4.8 & 2.2 & 2.4 & $\overline{2} .5$ & 3.2 & 3.3 & 5.0 & 4.6 & 4.6 \\
\hline & & \pm 0.5 & \pm 0.1 & $\pm 0.4^{*}$ & $\pm 0.2^{*}$ & $\pm 0.1^{*}$ & \pm 0.5 & \pm 0.7 & \pm 0.3 & \pm 0.6 & \pm 0.7 \\
\hline & Saline & $\overline{5} .0$ & 5.0 & 2.9 & $\overline{3} .0$ & $\overline{3.4}$ & 2.5 & 4.9 & 3.0 & 4.1 & 3.0 \\
\hline & & \pm 0.5 & \pm 0.1 & \pm 0.3 & \pm 0.6 & +0.3 & \pm 1.0 & \pm 0.2 & +0.7 & \pm 0.0 & \pm 0.3 \\
\hline & & \multicolumn{10}{|c|}{ Secondary immune response } \\
\hline \multirow{3}{*}{ High } & SRBC & 3.4 & 1.7 & 0.6 & 1.1 & 1.6 & 1.8 & 2.0 & 2.0 & 1.4 & 3.4 \\
\hline & & $+\underline{+0 .} 2$ & \pm 0.7 & $+0.3^{*}$ & \pm 0.2 & \pm 0.4 & \pm 0.3 & \pm 0.5 & \pm 0.3 & \pm 0.2 & \pm 0.7 \\
\hline & Saline & 2.5 & 1.4 & $\overline{2} .0$ & 1.4 & 1.4 & 1.9 & 2.1 & 2.2 & 1.4 & 2.5 \\
\hline \multirow{5}{*}{ Low } & & +0.1 & +0.2 & +0.4 & +0.9 & +0.1 & +1.2 & +0.1 & +0.1 & +0.2 & +0.1 \\
\hline & SRBC & $\overline{2} .6$ & $\overline{2} .0$ & $\overline{1.2}$ & $\overline{1} .4$ & $\overline{1} .6$ & $\overline{1} .9$ & $\overline{1.9}$ & $\overline{3} .0$ & $\overline{2} .0$ & $\overline{2.6}$ \\
\hline & & \pm 0.1 & \pm 0.1 & \pm 0.2 & \pm 0.9 & \pm 0.3 & \pm 0.2 & \pm 0.7 & \pm 0.9 & \pm 0.2 & \pm 0.1 \\
\hline & Saline & 3.6 & 1.7 & 1.6 & $\overline{1.3}$ & 2.3 & 2.1 & $\overline{0} .8$ & 2.6 & 1.9 & $\overline{3} .6$ \\
\hline & & \pm 0.6 & \pm 0.7 & \pm 0.6 & \pm 0.5 & \pm 0.9 & \pm 0.3 & \pm 0.3 & \pm 0.2 & \pm 0.8 & \pm 0.7 \\
\hline
\end{tabular}

Table 3. Variations in serum $T_{3}$ level ( $\mathrm{n} \mathrm{mol} / \mathrm{L}$ )of high and low lines of Fayoumi chickens over the time of primary and secondary immune response

\begin{tabular}{|c|c|c|c|c|c|c|c|c|c|c|}
\hline \multirow{3}{*}{ Line } & \multicolumn{10}{|c|}{ Primary immune response } \\
\hline & \multicolumn{7}{|c|}{ Time post injection ( Hours) } & \multicolumn{3}{|c|}{$\begin{array}{c}\text { Time post injection } \\
\text { (days) }\end{array}$} \\
\hline & 0 & 1 & 3 & 6 & 9 & 12 & 24 & 3 & 7 & 10 \\
\hline \multirow[t]{2}{*}{ High } & 4.2 & 3.9 & 2.2 & 2.4 & 2.6 & 2.9 & 2.8 & 3.8 & 3.2 & 3.0 \\
\hline & \pm 0.6 & \pm 0.4 & \pm 0.7 & \pm 0.8 & \pm 0.2 & +0.2 & \pm 0.2 & \pm 0.7 & \pm 0.2 & \pm 0.6 \\
\hline \multirow[t]{3}{*}{ Low } & 5.0 & 4.8 & 2.2 & 2.4 & 2.5 & 3.2 & 3.3 & 5.0 & 4.6 & 4.6 \\
\hline & \pm 0.5 & \pm 0.1 & $\pm 0.4^{*}$ & $\pm 0.2^{*}$ & $\underline{+0 .} .1^{*}$ & +0.5 & \pm 1.7 & \pm 0.3 & \pm 0.6 & \pm 0.7 \\
\hline & \multicolumn{10}{|c|}{ Secondary immune response } \\
\hline High & 2.9 & 1.6 & 1.3 & 1.3 & 1.0 & 1.9 & 2.0 & 2.1 & 1.4 & 35.1 \\
\hline & \pm 1.0 & $\underline{+0.5}$ & \pm 0.3 & \pm 0.4 & \pm 0.3 & +0.5 & \pm 0.6 & \pm 0.5 & $\underline{+0} .1$ & \pm 0.1 \\
\hline Low & 3.1 & $\overline{1.9}$ & 1.4 & 1.3 & 1.9 & 2.0 & 1.4 & 2.8 & $\overline{2.0}$ & 30.2 \\
\hline & \pm 0.6 & \pm 0.5 & +0.3 & \pm 0.3 & \pm 0.4 & +0.9 & \pm 0.4 & \pm 0.6 & +0.7 & +4.9 \\
\hline
\end{tabular}

* Indicate significance $(\mathrm{P}<0.05)$ compared to $0 \mathrm{hr}$. within each line and immune response.

+ No significant differences were observed between lines at any specific time point.

On the other hand, Gehad (2000) explained that the level of $\mathrm{T}_{3}$ is affected by the nature of antigen stimulating specific humoral immune response. He observed that injection of lipopolysaccharide (LPS) antigen (T-independent antigen) causes significant decrease of $\mathrm{T}_{3}$ and $\mathrm{T}_{4}$ levels during the first day post-antigen injection. They in turn cause releasing of cytokines (IL-1 and TNF- $\alpha$ ) from macrophages with subsequent inhibition of thyrotropin release from the pituitary gland (Dibuis et al., 
1988 and Pange et al., 1989). Moreover, Kahl et al. (2000) clarified that injection of LPS reduces the activity of the enzyme 5-diiodinase that converts $T_{4}$ to $T_{3}$ in the liver. On the contrary to LPS antigen, Gehad (2000) found that bovine serum albumin (BSA) (T-dependent antigen) injection causes no significant change in level of $\mathrm{T}_{3}$ in the plasma because BSA does not stimulate the secretion of neither IL-1 nor TNF- $\alpha$.

\section{B) Profile of serum corticosterone hormone.}

The change in corticosterone levels during primary and secondary immune response within $\mathrm{H}$ and $\mathrm{L}$ lines are shown in Table 4. The results showed that in both line, SRBC injected birds had no significant change at any sampling time along the first $12 \mathrm{~h}$ comparing to that at $0 \mathrm{~h}$ (except that at $6 \mathrm{~h}$ post secondary injection of $\mathrm{L}$ line). On the other hand, there was a significant increase in corticosterone level at 24 $\mathrm{h}$ as well as at 3, 7 and 10 days post primary injection, ant at 3,7 and 10 days post secondary injection as comparing with $0 \mathrm{~h}$. Within saline injected group and during primary response, there was a significant increase in corticosterone level within $\mathrm{H}$ line throughout the first $12 \mathrm{~h}$ and at 3 and $6 \mathrm{~h}$ in L line as compared to $0 \mathrm{~h}$. In respect of secondary immune injection the high level of corticosterone was remarked in both line at $6 \mathrm{~h}$ only as comparing with $0 \mathrm{~h}$.

However, corticosterone level of SRBC injected birds were significantly higher at 3, 7 and 10 days than that of saline injected birds at the same time point. Regardless the type of injection, the current results showed that the pooled means of corticosterone levels of $\mathrm{H}$ line are significantly higher than $\mathrm{L}$ line at $1 \mathrm{~h}$ post primary injection and at $3 \mathrm{~h}$ post secondary injection. On the other hand, the vise versa was observed post secondary injection. However, no differences were observed between serum corticosterone of $\mathrm{H}$ and $\mathrm{L}$ lines at the remaining time point post primary or secondary injection (Table 5). The results in both line showed that pooled mean of corticosterone level were significantly higher at 3,7 and 10 post primary injection, and at $6 \mathrm{~h}$ as well as7d in $\mathrm{L}$ line and at $7 \mathrm{~d}$ in $\mathrm{H}$ line post secondary injection.

Additionally, the significant change of corticosterone level along $24 \mathrm{hrs}$ is partially in agreement with Gehad (2000), who observed that BSA antigen (Tdependent and non-pathogenic) does not produce a significant change of corticosterone level along $24 \mathrm{hrs}$ post antigen injection on contrary to lipopolysaccharide (LPS) antigen that induces significant rise of corticosterone level at 3 and $6 \mathrm{hrs}$ post antigen injection. He concluded that LPS stimulates production of IL-1 that in turn stimulates HPA-axis.

Besedovsky et al. (1977) found when rodents injected with SRBC's plasma cortricosterone elevated at 5-7 days after immune stimulation. Moreover, StenzelPoore et al. (1993) reported that the maximum significant increase of corticosterone level at 7 days associated with maximum level of antibody production. Mashlay et al. (1998) reported that the rise of corticosterone level may resulted from direct stimulation of antigen (SRBC) on leucocytes to produce CRF, which in turn stimulate ACTH production from anterior pituitary and/or leucocytes. Additionally it was previously mentioned that T-lymphocytes are capable of producing CRF (Kravchenco and Furalev, 1994) and ACTH (Lynos and Blalock, 1995) as well as macrophages produce ACTH (Hendricks and Mashaly, 1998). 
Abdou et al. 


\section{Second Experiment}

\section{Delayed type Hypersensitivity Test (DTH)}

The current results showed a time effect in both lines (Table 6). Within $\mathrm{H}$ line the reaction started as early as $3 \mathrm{hrs}$ post injection, increased markedly with the time, peaked at $12 \mathrm{hrs}$ and slightly decreased at $24 \mathrm{~h}$. However, No significant differences were recorded during the first $6 \mathrm{hrs}$ post injection. On the other hand, DTH response at 9,12 and $24 \mathrm{~h}$ occupied first with significant differences than at any other time. While within low line, the increase in wattle thickness was not recorded at $3 \mathrm{hrs}$ post injection, while it delayed till $6 \mathrm{hrs}$ and increased gradually, peaked significantly at 12 h. Gotto et al. (1977); Parmentier et al. (1996) and Gehad (2000), found that the DTH post injection characterized by rapid acute response that had started as early as $3 \mathrm{~h}$ and had peaked at $6 \mathrm{~h}$, where it showed a higher magnitude and still elevated till $24 \mathrm{~h}$, then the response ceased at $48 \mathrm{~h}$. This difference could be attributed to the genetic differences of birds that used in the experiments. The genetic control of delayed type hypersensitivity response was assigned to a locus linked to the Bcomplex (Rejci et al., 1974 and Taylor et al., 1987).

Table 6. Values of delayed type hypersensitivity test over the time post injection of high and low lines of Fayoumi chickens

\begin{tabular}{lcccccc}
\hline Line & \multicolumn{7}{c}{ Time post injection (hours) } \\
\cline { 2 - 7 } & Zero & $\mathbf{3}$ & $\mathbf{6}$ & $\mathbf{9}$ & $\mathbf{1 2}$ & $\mathbf{2 4}$ \\
\hline High & $100.0 \pm 0.0$ & $150.0 \pm 23.8$ & $166.6 \pm 33.3$ & $233.3 \pm 33.3^{*}$ & $300.0 \pm 0.0^{*+}$ & $277.0 \pm 25.0^{*^{+}}$ \\
Low & $100.0 \pm 0.0$ & $100.0 \pm 00.0$ & $133.3 \pm 33.3$ & $166.6 \pm 33.3$ & $200.0 \pm 0.0^{*}$ & $166.6 \pm 33.3$ \\
\hline
\end{tabular}

* Indicate significance $(\mathrm{P}<0.05)$ compared to $0 \mathrm{hr}$. within each treatment.

+ Indicate significance differences $(\mathrm{P}<0.05)$ between lines.

The early response to PHA-P is attributed to the direct effect of T-cell mitogen on the immune cells, where the sensitization period is not needed (Ptak et al., 1991). This mitogen activates macrophages, leading to release of IL-1 and TNF- J that result in expression of adhesiveness followed by extra-vascularization of leucocytes (Binns et al., 1990 and 1992). Moreover local oedema in response to PHA-P could also be attributed to slow degranulation of vasoactive amines from stimulated basophiles that accumulate around the injected area (Dvorak et al., 1981 and Ptak et al., 1991).

Gehad (2000) observed that injection of PHA-P into the wattle decreased the percentage of CD3+ cells (all $\mathrm{T}$ lymphocytes) in the circulation within $2 \mathrm{hrs}$ and CD8+ cells by 2 and $6 \mathrm{hrs}$ post injection; as well as CD4+ cells showed a decrease in the circulation by $2 \mathrm{hrs}$ post injection. All these observations have been account for migration of $\mathrm{CD} 3+, \mathrm{CD} 8+, \mathrm{CD} 4+$ from the peripheral circulation to the wattle; as PHA-P can initiate this migratory effect from the circulation through the induction of homing receptors on the tissues that can be recognized by peripheral lymphocytes (Binns et al., 1990). Gehad's observations was previously reported by Parmentier et al. (1998), who found that the entry of blood lymphocytes to the skin sites injected with PHA-P was first detect by 2 hrs following injection, was maximal by $6 \mathrm{hrs}$ and disappeared by $48 \mathrm{hrs}$ following injection. Moreover, Van Loveren et al. (1983) found that CD4+ cells were recruited to the local sites of antigen injection in the early phases of DTH responses; where in the spleen there was a significant increase in splenic CD4+ cells by 2 hrs post injection. All the previously mentioned findings 
indicate the morphological changes in wattle's skin along $24 \mathrm{hrs}$ post injection in our study.

The comparison between line in DTH response explain that $\mathrm{H}$ line had higher value at 12 and $24 \mathrm{~h}$ than that in L line at the same time point. these results are in agreement with the findings of Scott et al. (1991) and Parmentier et al. (1993), who have found that the in vivo mitogen responses to both con-A and PHA-P were higher in $\mathrm{H}$ line than those of L line. Parmentier et al. (1993) have explained his results on the basis of lower T-cell activity in the L line and higher CD4+ / CD8+ T-cell ratio in the high line. On the other hand, Ahmed. (2004) showed no significant differences between wattle thickness of high and low lines of Fayoumi chickens. These differences may be attributed to the difference in antigen used; since he used a bovine serum albumin not PHA-P.

The previous findings indicate that the divergent selection for humoral immune responsiveness in poultry will positively related and improve cell-mediated immune parameters. Also the acute intermediate wattle swelling in response to PHA-P can be used as an informative parameter for divergent selection for humoral immunity.

\section{Hormonal Profile Changes During Delayed Type Hypersensitivity}

\section{A. Profile of serum $T_{3}$ hormone}

The results in Table 7 indicate that there was no change remarked in the level of $\mathrm{T}_{3}$ between PHA-P and saline injected birds at any time point following injection within both lines. However within PHA-P injected birds, the hormone level decreased at $6 \mathrm{hrs}$ post injection as compared with $0 \mathrm{~h}$ without significance difference, then the level of hormone returned gradually to the base level at 9, 12 and 24 hrs., Irrespective the type of injection the results indicated that, the profile of $\mathrm{T}_{3}$ within L line was identical to that of $\mathrm{H}$ line (Figure1).

The present results are in agreement with those of Weetman et al. (1984); Bachman and Mashaly (1987) and Gehad (2000), who found no significant effect of PHA-P injection on the level of circulating T3. Bachman and Mashaly (1987) concluded that $\mathrm{T}_{3}$ level is lower than normal physiological level might be sufficient to maintain normal cell mediated immune response.

Table 7. Change in serum $T_{3}$ level (n mol/L) in PHA-P and saline injected birds of high and low lines of Fayoumi chickens

\begin{tabular}{llcccccc}
\hline Line & Treatment & \multicolumn{7}{c}{ Time post injection ( hours ) } \\
\cline { 3 - 8 } & & Zero & $\mathbf{3}$ & $\mathbf{6}$ & $\mathbf{9}$ & $\mathbf{1 2}$ & $\mathbf{2 4}$ \\
\hline \multirow{2}{*}{ High } & PHA & $3.1 \pm 0.5$ & $2.9 \pm 0.1$ & $2.2 \pm 0.4$ & $3.4 \pm 0.9$ & $3.1 \pm 0.8$ & $3.0 \pm 0.3$ \\
& Saline & $3.1 \pm 0.5$ & $3.1 \pm 0.1$ & $3.2 \pm 0.3$ & $3.9 \pm 1.6$ & $4.0 \pm 0.9$ & $4.6 \pm 0.5$ \\
Low & PHA & $4.2 \pm 0.5$ & $3.2 \pm 0.1$ & $2.9 \pm 0.0$ & $3.1 \pm 0.5$ & $3.8 \pm 0.1$ & $4.0 \pm 0.5$ \\
& Saline & $4.2 \pm 0.5$ & $2.9 \pm 0.5$ & $3.4 \pm 0.2$ & $3.5 \pm 0.2$ & $4.6 \pm 0.2$ & $3.2 \pm 0.2$ \\
\hline
\end{tabular}




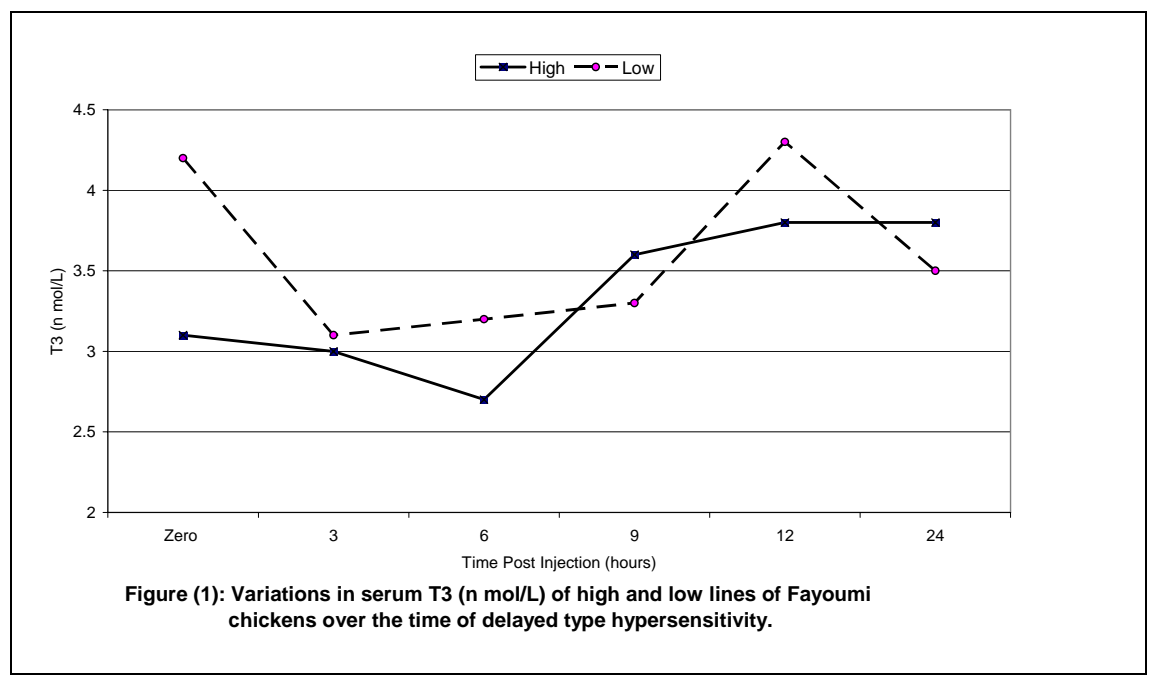

B. Profile of serum corticosterone hormone

The results of corticosterone level indicated that there were no significant changes between PHA-P and saline injected birds at any sampling time within both $\mathrm{H}$ and $\mathrm{L}$ lines (Table 8). Additionally, within PHA-P or saline injected birds, no differences were observed in corticosterone levels at any sampling time point. Also, no differences between corticosterone concentration of $\mathrm{H}$ and $\mathrm{L}$ lines (Figure 2). The insignificant changes of corticosterone hormone following PHA-P injection are in agreement with those of Binns et al. (1992); Chrsousos (1995) and Gehad (2000), who found that DTH in chicken injected with PHA-P can proceed without actual stimulation of HPA-axis. This is due to absence of pro-inflammatory cytokines in mitogenic reaction.

Table 8. Change in serum corticosterone level (ng/ml) of PHA-P and saline injected birds of high and low lines of Fayoumi chickens

\begin{tabular}{llcccccc}
\hline Line & \multirow{2}{*}{ Treatment } & \multicolumn{7}{c}{ Time post injection ( hours ) } \\
\cline { 3 - 8 } & & Zero & $\mathbf{3}$ & $\mathbf{6}$ & $\mathbf{9}$ & $\mathbf{1 2}$ & $\mathbf{2 4}$ \\
\hline \multirow{2}{*}{ High } & PHA & 507.5 & 534.1 & 568.6 & 510.8 & 508.0 & 507.5 \\
& & \pm 4.6 & \pm 41.2 & \pm 26.5 & \pm 8.5 & \pm 26.2 & \pm 4.6 \\
& \multirow{2}{*}{ Saline } & 507.5 & 513.6 & 482.3 & 527.0 & 509.0 & 519.6 \\
& & \pm 4.6 & \pm 11.4 & \pm 18.9 & \pm 50.2 & \pm 5.8 & \pm 11.4 \\
Low & PHA & 513.6 & 527.1 & 524.8 & 509.6 & 482.3 & 510.0 \\
& & \pm 11.4 & \pm 50.0 & \pm 34.1 & \pm 5.0 & \pm 78.0 & \pm 8.5 \\
& \multirow{2}{*}{ Saline } & 513.68 & 524.8 & 527.1 & 514.0 & 508.0 & 566.8 \\
& & \pm 11.4 & \pm 34.1 & $\underline{ \pm 0.2}$ & $\underline{ \pm 11.1}$ & \pm 26.2 & \pm 14.3 \\
\hline
\end{tabular}

In conclusion, the current study may explain that the initiation of humoral immune response involves the activation of HPT- and HPA-axis, which results in a decrease in $\mathrm{T}_{3}$ levels and an increase in serum corticosterone levels post primary and 
secondary SRBC injection. While this axis is not involved in delayed type hypersensitivity reaction.

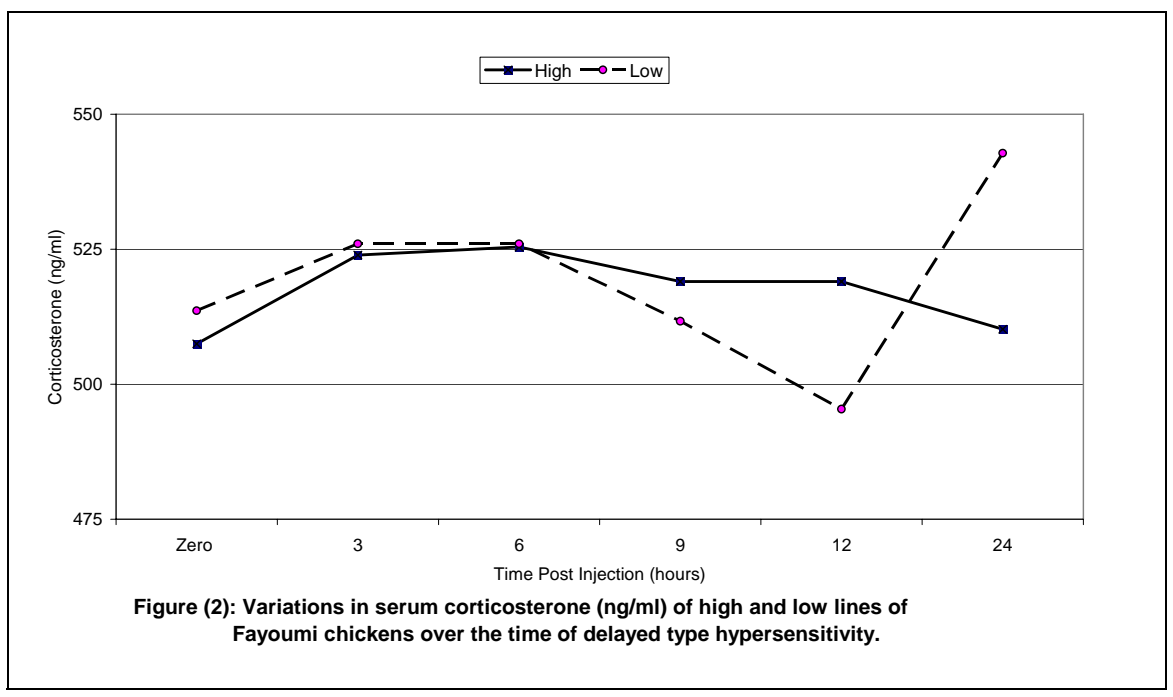

\section{REFERENCES}

Ahmed, S.A., 2004. The effect of selection for antibody level against sheep red blood cells on some physiological and economical parameters in Fayoumi chickens. Ph.D. Thesis. Faculty of Agriculture, Cairo University. Egypt.

Atta, A.M., 2002. The effect of T-dependent antigen on the profiles of circulating white blood cells, corticosterone, $\mathrm{T}_{3}, \mathrm{~T}_{4}$ and glucose during the initiation of humoral immune response in white leghorn cockerels. J. Agricult. Sci., Mansoura Univ. 27: 4483-4494.

Bachman, S.E. and M.M. Mashaly, 1987. Relationship between circulating thyroid hormones and cell-mediated immunity in immature male chickens. Dev. \& Comp. Immunol. 11: 203-213.

Besedovsky, H., E. Sorkin, D. Felix and H. Haas, 1977. Hypothalamic changes during the immune response. Eur. J. Immunol. 7: 323-325.

Binns, R.M., S.T. Licence and. F.B.P. Wooding, 1990. Phytohemagglutinin induces major short-term protease sensitivity lymphocyte traffic involving high endothelium venule-like vessels in acute delayed-type hypersensitivity-like reaction in skin and other tissue. Eur. J. Immunol. 20: 1067-1071.

Binns, R.M., S.T. Licence, F.B.P. Wooding and W.P.H. Duffus, 1992. Active lymphocyte traffic induced in the periphery by cytokines and phytohemagglutinin: three different mechanisms. Eur. J. Immunol. 22: 21952230 . 
Biozzi, G., D. Mouton, A.M. Heumann, and Y. Bouthilier, 1982. Genetic regulation of immune responsiveness in relation to resistance to infectious diseases. Proc. $2^{\text {nd }}$ World Congress on Genetics Applied to Livestock Production, Madried, Spain, 5: 150-163.

Chrsousos, G.P., 1995. The hypothalamic pituitary-adrenal axis and immune mediated inflammation. N. Engl. J. Med. 332: 1351-1361.

Davis, S.L., 1998. Environmental modulation of the immune system via the endocrine system. Dom. Animal Endocrinol. 15: 283-289.

Dibuis, J. M., J. M. Dayer, C. D. Siegrist-Kaiser and A.G. Burger, 1988. Human recombinant IL-1 beta plasma thyroid hormone and thyroid stimulating hormone levels in rats. Endocrinology. 123: 2175-2181.

Duncan, D.B., 1955. Multiple range and multiple F-Tests. Biometrics 11: 1 - 42

Dvorak, A.M., S.J. Gallis, E. Morgan, A.S. Galli and H.F. Dvorak, 1981. Anaphylactic degranulation of guinea pig basophilic leukocytes. 1. Fusion of granule membranes and cytoplasmic vesicles. Formation and resolution of degranulation sac. Lab. Invest. 44: 174-191.

Gehad, A.E., 2000. The interaction of the immune and endocrine system and the distribution of lymphocyte populations during the initiation of humoral and cellmediated immunity in immature male chickens. Thesis for the Ph.D. Faculty of Agriculture, The Pennsylvania State University.

Gehad, A.E., M.M. Mashaly, H.S. Siegel, E.A. Dunnington and P.B. Siegel, 1999. Effect of genetic selection and MHC haplotypes on lymphocyte proliferation and interleukin-2 like activity in chicken lines selected for high and low antibody production against sheep red blood cells. Vet. Immunol. Immunopatho. 68: 13-24.

Gotto, N., H. Kodama, K. Okada and Y. Fujimoto, 1977. Suppression of phytohemaglutinin skin response in thymectomized chickens. Poultry Sci. 56: 246-250.

Hendricks, G.L. and M.M. Mashaly, 1998. Corticotropin releasing factor on the production of adrenocorticotropic hormone by leukocyte populations. Br. Poultry Sci. 39: 123-127.

Kahl, S., T.H. Elasser and J.W. Blum, 2000. Effect of endotoxin challenge on hepatic 5-deiodinase activity in cattle. Domestic Animal Endocrinology. 18: 133-143.

Kravchenco, I.V. and V.A. Furalev, 1994. Secretion of immunoreactive corticotropin releasing factor and adreno-corticotropic hormone by T-and B-lymphocyte in response to cellular stress factors. Biochem. Biophys. Res. Commun. 204: 82834.

Kreukniet, M.B., N. Gianotten, M.G.B. Nieuwland and H.K. Parmentier, 1996. In vitro T-cell activity in two chicken lines divergently selected for antibody response to sheep erythrocytes. Ph.D. Thesis, University of Wageningen, The Netherlands, pp. 85-90.

Kruger, T.E., 1996. Immunodulation of peripheral lymphocytes by hormones of the hypothalamus-pituitary-thyroid axis. Adv. Neuro Immunol. 6: 387-395.

Lyons P.D. and. J.E Blalock, 1995. The kinetics of ACTH expression in rat leukocyte sub-populations. J. Neuroimmunol. 63: 103-112.

Marsh, J.A., 1992. Neuroendocrine-immune interactions in the avian species. A review. Poultry Sci. Rev. 4: 129-167. 
Martin, F.M. and P.B. Siegel, 1988. Thiouracil and antibody titers of chickens from lines divergently selected for antibody response to sheep erythrocytes. Dev. Comp. Immunol. 12: 611.

Mashaly, M.M., J.M. Trout, G.L. Hendricks III, L.M. Al-Dokhi and A. Gehad, 1998. The role of neuroendocrine immune interactions in the initiation of humoral immunity in chickens. Dom. c Animal Endocrinol. 15: 409-422.

Murray, D.L., J.P. Thaxton and J. Brake, 1987. Effects of adrenocorticotropin and dietary ascorbic acid on cutaneous basophil hypersensitivity to phytohemagglutinin in chickens. Poultry Sci. 66: 1846-1852.

Nelson, N.A.; N. Lakshmanan and S.J. Lamont, 1995. Sheep red blood cell and brucella abortus antibody response in chickens selected for multitralt immunocompetence. Poultry Sci. 74: 1603-1609.

Pange, X.P., J.M. Hershman, C.J. Mirell and A. E. Pekary, 1989. Impairment of hypothalamic-pituitary-thyroid function in rats treated with (Cachectin). Indocrinology. 125:?human recombinant tumor necrosis factor- 76-84.

Parmentier, H.K., DeVries G. Reiling and M.G.B. Nieuwland, 1998. Kinetic and immuno-histochemical characteristics of mitogen-induced cutaneous hypersensitivity in chickens selected for antibody responsiveness. Vet. Immunol. Immunopathol. 66: 367-376.

Parmentier, H.K., M.G.B. Nieuwland, E. Rijke, G. De vries Reilingh and J.W. Schrama, 1996. Divergent antibody response to vaccine and divergent body weights of chicken lines selected for high and low humoral responsiveness to sheep red blood cells. Avian Dis. 40: 634-644.

Parmentier, H.K., J.W. Schrama, F. Meijer and M.G.B. Nieuwland, 1993. Cutaneous hypersensitivity response in chickens divergently selected for antibody to sheep blood cells. Poultry Sci. 72: 1679-1692.

Ptak, W., G.P. Geba and P.W. Askenase, 1991. Initiation of delayed-typehypersensitivity by low doses of monoclonal $\operatorname{IgE}$ antibody. Mediation by serotonin and inhibition by histamine. J. Immunol. 146: 3929-3969.

Rejci, K., K. Arakoz, I. Pekarek, J. Hrabat and K. Hala, 1974. Differences between inbred lines of chickens in development of tuberculin hypersensitivity. Immunol. 27: $133-136$.

SAS Institute, 2000. SAS/STAT User's Guide, statistics SAS Institute Inc. Cary, NC, USA.

Scott, T., E.A. Dunnington and P.B. Siegel, 1991. T-cell activity of white leghorn chickens selected for high and low antibody response to sheep erythrocytes. Poultry Sci. 70: 1831-1834.

Scott, T., E.A. Dunnington and P.B. Siegel, 1994. Brucella abortus antibody response of white leghorn chickens selected for high and low antibody responsiveness to sheep erythrocytes. Poultry Sci. 73: 346-349.

Siegel, H.S., H.K. Parmentier, M.G.B. Nieuwland, Van der Hel, W. and H.A. Brandsma, 1992. Differences in lymphocyte subpopulation in blood and spleen of two lines selected for antibody response after immunization and heat stress. Poultry Sci. 71: 13 (Abstr.).

Stenzel-Poore, M., W.W. Valve and C. Rivier, 1993. Relationship between antigeninduced immune stimulation and activation of the hypothalamic-pituitary-adrenal axis in the rat. Endocrinol. 132: 1313-1318. 
Taylor, R.L., P.F. Cotter, T.L. Wing and W.E. Briles, 1987. Major histocompatability (B) complex and sex effects on the PHA wattle response. Animal Genet. 18: 343500.

Trout, J.M., M.M. Mashaly, and H.S. Siegel, 1988. Changes in the profiles of circulating white blood cells corticosterone, $\mathrm{T}_{3}$ and $\mathrm{T}_{4}$ during the initiation of the humoral immunity in immature male chickens. Dev. Comp. Immunol. 12: 331346.

Van Der Zijpp, A.J. and F.R. Leenstera, 1980. Genetic analysis of the humoral immune response of White Leghorn chicks. Poultry Sci. 59:1363-1369.

Van Der Zijpp, A.J., M.B. Kruekniet and M.G.B. Nieuwland, 1989. Response to selection for high and low antibody production. Poultry Sci. 66: 188 (Abstr.)..

Van Loveren, H., R. Nleade and P.W. Askenase, 1983. An early component of delayed-type hypersensitivity mediated by T-cells and mast cells. J. Exp. Med. 157: $1604-1617$

Weetman, A.P., A.M. McGregor, M. Ludgate and R. Hall, 1984. Effect of triiodothyronxine on normal lymphocyte function. J. Endocrinol. 101: 81-86. 
تأثير الإنتخاب للإستجابة العالية والمنخفضة للأجسام المناعية المضادة لكرات الام الام الحمراء

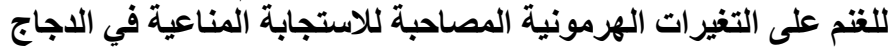

علاء الدين محمد عبده1، عبد الرحمن محمد عطاء، شكرى محمد طلبه الطنطاوي1، سلوى سالم

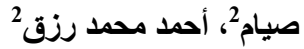

1- قسم الإنتاج الحيواني- كلية الزراعة - جامعة القاهرة، 2- معطج بحوث الإتتاج الحيواني - وزارة الزراعةالاققي

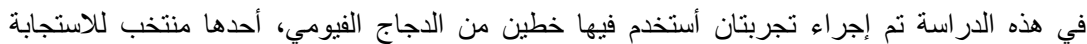

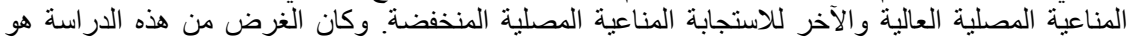

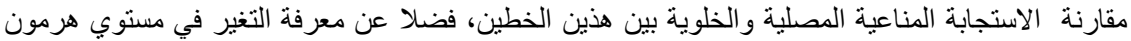

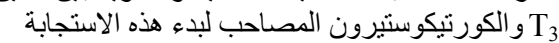

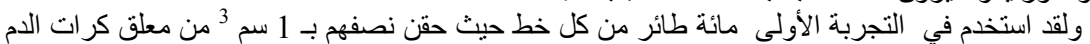

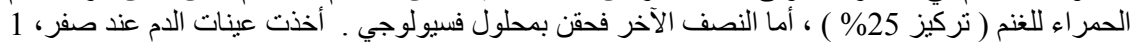

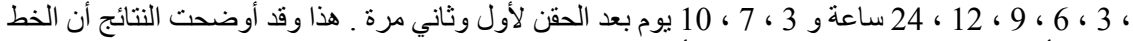

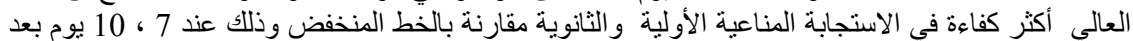

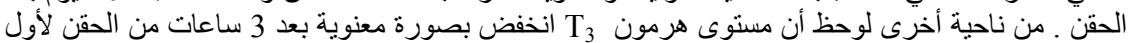

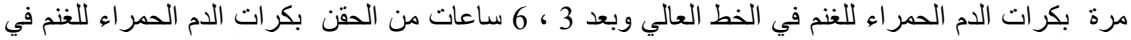

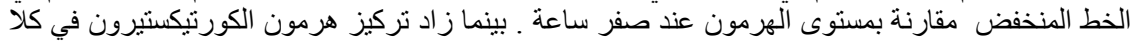

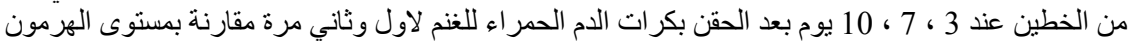

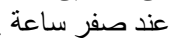
في التجربة الثنانية استخدم مائة و عشرون طائر من كلا الخطين حيث حقن نصفهر بمادة

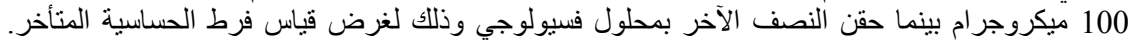

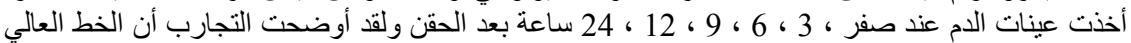

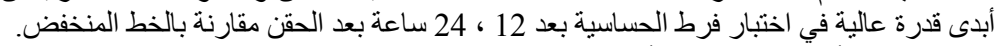

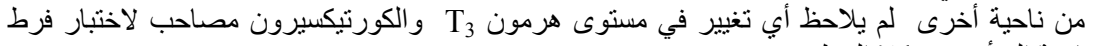
الحساسية المتأخر في كلا الخطين . الخرى 
Abdou et al. 
Table 4. Change in serum corticosterone level $(\mathrm{ng} / \mathrm{ml})$ in SRBC and saline injected of high and low lines of Fayoumi chicken

\begin{tabular}{|c|c|c|c|c|c|c|c|c|c|c|c|}
\hline \multirow{3}{*}{ Line } & \multirow{3}{*}{ Treatment } & \multicolumn{10}{|c|}{ Primary immune response } \\
\hline & & \multicolumn{7}{|c|}{ Time post injection ( Hours) } & \multicolumn{3}{|c|}{ Time post injection (days ) } \\
\hline & & 0 & 1 & 3 & 6 & 9 & 12 & 24 & 3 & 7 & 10 \\
\hline \multirow{4}{*}{ High } & SRBC & 25.4 & 35.1 & 164.9 & 120.6 & 91.6 & 38.9 & 275.2 & 484.5 & 527.8 & 480.9 \\
\hline & & \pm 2.4 & \pm 16.0 & \pm 58.9 & \pm 48.6 & \pm 26.7 & \pm 11.0 & $\pm 13.2^{*}$ & $\pm 28.0^{+*}$ & $\pm 45.0^{+*}$ & $\pm 69.2^{+*}$ \\
\hline & Saline & 25.4 & 162.2 & 207.6 & 183.2 & 175.3 & 172.3 & 87.8 & 59.6 & 45.3 & 37.3 \\
\hline & & \pm 2.4 & $\pm 81.7^{*}$ & $\pm 35.0^{*}$ & $+44.9^{*}$ & $\pm 20.1^{*}$ & $\pm 35.2^{*}$ & \pm 19.4 & \pm 5.2 & \pm 9.2 & \pm 6.6 \\
\hline \multirow{5}{*}{ Low } & SRBC & 29.2 & 30.1 & 115.4 & 97.3 & 87.8 & 37.7 & 172.3 & 444.8 & 458.8 & 373.5 \\
\hline & & \pm 1.3 & \pm 1.16 & \pm 39.4 & \pm 22.7 & \pm 19.4 & \pm 9.9 & $\pm 35.7^{*}$ & $\pm 21.0^{+*}$ & $\pm 20.0^{+*}$ & $\pm 39.3^{+*}$ \\
\hline & Saline & 29.2 & 38.9 & 172.3 & 120.6 & 91.6 & 87.3 & 73.8 & 59.4 & 35.14 & 60.1 \\
\hline & & \pm 1.3 & \pm 11.02 & $\pm 35.7^{*}$ & $\pm 48.6^{*}$ & \pm 26.7 & \pm 19.4 & \pm 19.9 & \pm 5.0 & \pm 3.6 & \pm 12.2 \\
\hline & & \multicolumn{10}{|c|}{ Secondary immune response } \\
\hline \multirow{4}{*}{ High } & SRBC & 23.5 & 30.7 & 88.8 & 84.9 & 75.6 & 74.9 & 37.3 & 207.6 & 458.5 & 275.2 \\
\hline & & \pm 4.8 & \pm 12.8 & \pm 12.4 & \pm 20.4 & \pm 8.6 & \pm 36.2 & \pm 6.6 & $\pm 35.0^{+*}$ & $\pm 45.0^{+*}$ & $\pm 29.5^{+*}$ \\
\hline & Saline & 23.5 & 30.6 & 89.9 & 176.9 & 91.6 & 69.7 & 52.7 & 59.4 & 37.3 & 35.1 \\
\hline & & \pm 4.2 & \pm 3.4 & +58.9 & $\pm 24.2^{*}$ & \pm 26.7 & \pm 21.7 & \pm 3.9 & \pm 5.1 & \pm 6.6 & \pm 16.0 \\
\hline \multirow{4}{*}{ Low } & SRBC & 28.4 & 45.3 & 91.6 & 165.5 & 81.2 & 75.6 & 55.5 & 180.1 & 458.5 & 190.6 \\
\hline & & \pm 6.4 & \pm 9.2 & \pm 26.7 & $\pm 10.4^{*}$ & \pm 28.5 & \pm 8.5 & \pm 14.2 & $\pm 50.0^{+*}$ & $\pm 48.0^{+*}$ & $\pm 54.2^{+*}$ \\
\hline & Saline & 28.4 & 87.8 & 120.8 & 164.9 & 75.6 & 62.9 & 51.1 & 63.01 & 61.6 & 30.2 \\
\hline & & \pm 6.49 & \pm 19.4 & \pm 19.4 & $+58.9^{*}$ & \pm 8.5 & \pm 28.0 & \pm 14.2 & \pm 31.9 & \pm 9.4 & \pm 4.9 \\
\hline
\end{tabular}

* Indicate significance $(\mathrm{P}<0.05)$ compared to $0 \mathrm{hr}$. within each treatment.

+ Indicate significance differences $(\mathrm{P}<0.05)$ between treatment (SRBS or saline ) within immune response at any specific time point. 
Table 5. Variations in serum corticosterone levels $(\mathrm{ng} / \mathrm{ml})$ of high and low lines of Fayoumi chickens over the time of primary and secondary immune response

\begin{tabular}{|c|c|c|c|c|c|c|c|c|c|c|}
\hline \multirow{3}{*}{ Line } & \multicolumn{10}{|c|}{ Primary immune response } \\
\hline & \multicolumn{7}{|c|}{ Time post injection ( Hours) } & \multicolumn{3}{|c|}{ Time post injection (days) } \\
\hline & $\mathbf{0}$ & 1 & 3 & 6 & 9 & 12 & 24 & 3 & 7 & 10 \\
\hline \multirow[t]{2}{*}{ High } & 25.4 & 98.6 & 186.3 & 151.9 & 133.4 & 105.6 & 181.5 & 272.1 & 286.6 & 259.1 \\
\hline & \pm 2.4 & $\pm 33.3^{+}$ & +32.1 & +32.1 & +24.0 & +34.1 & +19.4 & $+95.9^{*}$ & $+10.9^{*}$ & $\pm 10.4 *$ \\
\hline \multirow[t]{3}{*}{ Low } & 29.2 & 34.5 & 151.6 & 118.0 & 89.7 & 62.7 & 123.1 & 252.1 & 246.0 & 373.1 \\
\hline & +1.3 & +5.3 & +19.1 & +28.0 & +14.8 & \pm 14.8 & +28.2 & $+86.7^{*}$ & $+96.8^{*}$ & $+39.3^{*}$ \\
\hline & \multicolumn{10}{|c|}{ Secondary immune response } \\
\hline \multirow[t]{2}{*}{ High } & 23.5 & 30.7 & 165.0 & 128.6 & 83.6 & 72.3 & 47.5 & 133.5 & 274.9 & 155.2 \\
\hline & \pm 2.9 & $\pm 1.6^{+}$ & $\pm 37.2^{+} *$ & \pm 26.8 & \pm 13.0 & \pm 18.9 & \pm 3.9 & \pm 36.7 & $\pm 96.4^{*}$ & \pm 52.7 \\
\hline \multirow[t]{2}{*}{ Low } & 28.4 & 66.6 & 106.1 & 165.2 & 78.4 & 64.2 & 55.5 & 121.6 & 266.1 & 110.4 \\
\hline & +4.1 & \pm 13.5 & \pm 12.5 & $\pm 23.7^{*}$ & \pm 13.4 & \pm 13.4 & \pm 9.0 & \pm 37.3 & $\pm 9.4^{*}$ & +43.3 \\
\hline
\end{tabular}

* Indicate significance $(\mathrm{P}<0.05)$ compared to $0 \mathrm{hr}$. within each line and immune response.

+ Indicate significance differences $(\mathrm{P}<0.05)$ between lines within immune response at any specific time point. 